\title{
INSTRUMENTASI PEMANTAUAN JARAK JAUH UNTUK MENGUKUR KINERJA TURBIN ARUS PASANG SURUT LAUT
}

\author{
INSTRUMENTATION OF REMOTE MONITORING TO MEASURING THE PERFORMANCE \\ OF MARINE TIDAL TURBINE
}

\author{
Hadhi Nugroho dan Dwiyoga Nugroho \\ Pusat Pengkajian dan Perekayasaan Teknologi Kelautan dan Perikanan, Balitbang KP, KKP \\ Jl. Pasir Putih I, Ancol Timur, Jakarta Utara \\ E-mail: hadhinugroho@gmail.com
}

Diterima tanggal: 16 Januari 2014, diterima setelah perbaikan: 10 Maret 2014, disetujui tanggal: 14 Maret 2014

\begin{abstract}
ABSTRAK
Tulisan ini menjelaskan tentang sistem instrumentasi yang dapat diaplikasikan pada turbin arus pasang surut laut. Sistem instrumentasi pada turbin arus pasang surut laut ini meliputi seperangkat sensor pembaca parameter kinerja turbin, perekam data untuk mencatat dan menyimpan data yang dihasilkan sensor, dan sistem telemetri untuk mengirim data ke operator turbin. Sistem instrumentasi tersebut digunakan agar kinerja turbin arus pasang surut laut yang dipasang di suatu tempat dapat dipantau dari jarak jauh secara kontinu dan real time.Tujuan penelitian instrumentasi pengukuran kinerja turbin arus pasang surut laut adalah untuk merancang dan menguji sistem instrumentasi dalam mencatat, menyimpan, dan mengirimkan data parameter kinerja turbin. Pengujian dilakukan di perairan Muara Karang, Jakarta pada 15 November - 25 Desember 2012. Data parameter kinerja turbin yang diambil meliputi teganganlistrik generator, arus listrik generator, putaran turbin, serta tegangan baterai. Data tersebut akan tersimpan pada perekam data dengan kerapatan data(sampling rate) setiap 8 detik. Data tersebut juga akan dikirim ke operator turbin, dengan waktu pengiriman data setiap satu jam, yang berisi data parameter kinerja turbin setiap 5 menit. Dari data hasil uji coba, dapat dibuat grafik hubungan antara putaran turbin dengan tegangan generator dan putaran turbin dengan daya generator. Pada grafik putaran turbin dengan tegangan generator dan putaran turbin dengan daya generator, diperoleh hasil bahwa secara umum tegangan generator dan daya generator akan naik seiring dengan kenaikan putaran turbin, dengan kenaikan bersifat fluktuatif. Dari data pengujian, dapat disimpulkan bahwa perangkat keras instrumentasi turbin arus pasang surut laut telah berhasil dibuat dan dapat berfungsi dengan baik dalam mencatat, menyimpan, dan mengirimkan data parameter kinerja turbin.
\end{abstract}

Kata kunci: instrumentasi, telemetri, turbin

\section{ABSTRACT}

This paper describes the instrumentation system that can be applied to the marine tidal turbine.This system consist of the sensor to read turbine performance parameter, the data logger to record and save data from the sensor, and telemetric system to sending data to turbin operator. With this system, performance of marine tidal turbine can be monitor from long distance place by continue and real time. The aim of this research is to trial and test instrumentation system of turbine in recording, saving, and sending the data of turbine performance parameter. To obtain performance and efficiency of this turbine, trial and test have been carried out in Muara Karang, Jakarta at November $15^{\text {th }}$ until December $25^{\text {th }}$, 2012. The measured data of turbine performance parameter aregenerator voltage, generatorcurrent, turbine rotation, and battery voltage.The data will be saved in data logger with interval 8 second. The data is also sent to turbine operator every 1 hour, containing the turbine data every 5 minutes. From the trial data, we can make a graph of the voltage generator with turbine rotation and the power generator with turbine rotation. In the graph of voltage generator with turbine rotation, the results showed that in general the voltage generators and power generators will rise due to higher turbine rotation, with the increase fluctuated.From the trial data, it can be concluded that the hardware of marine tidal turbine instrumentation is success and good functioned in recording, storing, and transmitting data turbine performance parameters.

Keywords: instrumentation, telemetric, turbine

Instrumentasi Pemantauan Jarak Jauh untuk Mengukur Kinerja Turbin Arus Pasang Surut Laut - Hadhi Nugroho dan Dwiyoga Nugroho 


\section{PENDAHULUAN}

Instrumentasimemiliki tiga fungsi dasar, yaitu penunjukan (indicating), pencatatan (recording), dan pengendalian (control). Instrumentasi pengujian kuantitas listrik dan elektronika umumnya berfungsi untuk penunjukan dan pencatatan, sedangkan yang digunakan pada proses industri kebanyakan ditujukan untuk fungsi pengendalian/kontrol (Warsito, 2009).

Sistem instrumentasi dapat diaplikasikan pada turbin arus pasang surut laut untuk mengukur dan memantau parameter kinerja turbin. Sistem turbin tersebut bekerja secara terus-menerus di lokasi operasi yang tidak selalu dapat terjangkau oleh operator turbin. Oleh karena itu diperlukan perangkat pendukung operasi sistem turbin berupa sistem instrumentasi. Sistem instrumentasi tersebut digunakan agar kinerja turbin arus pasang surut laut yang dipasang di suatu tempat dapat dipantau dari jarak jauh secara kontinu dan real time. Sehingga gejala kegagalan atau kerusakan yang mungkin terjadi pada turbin dapat diantisipasi secara cepat.

Sistem instrumentasi pada turbin arus pasang surut laut ini meliputi seperangkat sensor pembaca parameter kinerja turbin, perekam data (data logger) untuk mencatat dan menyimpan data yang dihasilkan sensor, dan sistem telemetri untuk mengirim data ke operator turbin. Sensor adalah sebuah perangkat yang berfungsi mengubah suatu besaran fisik menjadi besaran listrik, sehingga keluarannya dapat diolah dengan rangkaian listrikatau sistem digital (Setiawan, 2009).

Perekam data adalah alat elektronik yang digunakan untuk mencatat atau merekam data dari waktu ke waktu, yang memiliki kemampuan secara otomatis untuk mengumpulkan data selama 24 jam (Anonim, 2011). Sedangkan telemetri merupakan suatu proses yang digunakan untuk mengukur atau mencatat suatu besaran fisik pada suatu lokasi yang letaknya jauh dari pusat pengolahan hasil pengukuran (Darajat, Komarudin \& Sulistiyanti 2012).

Sistem telemetri sering digunakan untuk pengukuran di daerah-daerah yang sukar dijangkau manusia atau untuk pemantauan terus-menerus yang tidak memungkinkan petugas untuk melakukan pengukuran secara terus-menerus, sehingga petugas cukup meletakkan alat ukur pada tempat pengukuran dan dapat dipantau dari tempat lain (Sukiswo, 2005).

Sistem jaringan GSM (Global System for Mobile Communication) dinilai dapat secara efektif digunakan untuk keperluan telemetri pada sistem turbin arus pasang surut laut. GSM merupakan salah satu teknologi telekomunikasi bergerak generasi kedua (2G). Salah satu keunggulan GSM adalah kemampuan roaming yang luas sehingga dapat dipakai di berbagai negara, meyebabkan pertumbuhannya sangat pesat (Pasaribu, 2006). Roaming adalah kemampuan yang dimilliki oleh jaringan bergerak seluler yang memungkinkan penggunanya untuk tetap dapat menggunakan layanan di daerah yang belum terlayani oleh suatu penyelenggara jaringan bergerak seluler dengan menggunakan jaringan milik penyelenggara jaringan bergerak seluler lainnya (Republik Indonesia, 2010). Kecepatan akses data pada jaringan GSM yaitu sekitar 9,6 kbps (Pasaribu, 2006). Teknologi ini memanfaatkan gelombang mikro dan pengiriman sinyal yang dibagi berdasarkan waktu, sehingga sinyal informasi yang dikirim akan sampai pada tujuan (Ariyus dan Andri, 2008). Menurut Syariman (2012), telemetri berbasis GSM sangat tergantung pada provider penyedia jasa layanan telekomunikasi. Semakin luas dan kuat jaringan layanan suatu provider, semakin kuat pemanfaatan jaringan telemetrinya. Kekuatan sinyal sangat ditentukan oleh banyaknya BTS (Base Transceiver Station) di lapangan. Dalam sistem telemetri berbasis GSM, yang dijadikan tolak ukur biaya operasional sistem telemetri adalah pemakaian pulsa.

SMS (Short Message Service) adalah salah satu layanan dari teknologi GSM. SMS adalah sebuah mekanisme penyampaian pesan pendek dalam jaringan bergerak (Syariman, 2012). Dengan menggunakan teknologi SMS, informasi-informasi tertentu dapat diakses secara mobile melalui mobile phone. Dipandang dari teknologinya (sistem dan cara kerjanya), SMS sangat cocok untuk diterapkan dalam aplikasi mobile alert (notification) dan info on demand (Rossy, Utomo \& Wellem, 2006).

Protokol yang bekerja pada SMS dikenal dengan nama Protocol Data Unit (PDU). Sebuah SMS dapat terdiri atas 160 karakter (skema 7 bit), 140 karakter (skema 8 bit), atau 70 karakter (skema 16 
bit). Saat ini pengiriman beberapa SMS dapat dilakukan sekaligus, demikian juga penggabungan SMS dan kompresi SMS yang melebihi dari 160 karakter (tidak terbatas) telah dikembangkan, seperti pada fitur ponsel BlackBerry ${ }^{\circledR}$ (Syariman, 2012).

Penelitian dan aplikasi sistem instrumentasi pada turbin atau pembangkit listrik sudah dilakukan beberapa kali di Indonesia. Wijayanto (2012) merancang dan membuat alat sistem pemantauan turbin pada generator mini-microhidro skala laboratorium berbasis mikrokontroler ATMEGA 8535. Sistem instrumentasi tersebut digunakan untuk mengetahui kecepatan putaran turbin dan tegangan yang dihasilkan generator. Pemantauan dilakukan secara on board monitoring, dimana data putaran turbin dan tegangan generator ditampilkan pada layar LCD (Liquid Crystal Display).

Oemry dan Djunaedi (2010) merancang dan membuat sistem pemantauan PLTH (pembangkit listrik tenaga hibrid). PLTH tersebut terdiri dari sel surya, turbin angin, dan fuel cell berbasis hidrogen. Energi listrik yang dihasilkan PLTH tersebut disalurkan untuk kepentingan masyarakat di Kampung Tenjolaya, Kecamatan Wanassalam, Kabupaten Lebak, Banten. Sistem pemantauan data dipasang untuk memantau semua data yang terkait dengan penentuan kinerja sistem, seperti data input photovoltaic, radiasi matahari, kecepatan angin, energi yang dikonversikan oleh unit elektrolisis menjadi gas hidrogen, gas yang dikonversikan kembali oleh fuel cell menjadi listrik, maupun data output penggunaan energi listrik. Sebanyak 18 sensor telah dipasang, dimana data dari masing-masing sensor ditampilkan pada layar monitor utama setiap 4 detik, dan disimpan pada database server lokal setiap 1 menit.Semua data di server lokal kemudian dikirim ke server di pusat dengan menggunakan 2 metode telemetri, yaitu melalui SMS (GSM) dan internet (GPRS).

Riyadi (2011) melakukan penelitian tentang sistem instrumentasi pada turbin gas yang diaplikasikan di industri gas alam cair. Instrumentasi digunakan untuk mengontrol temperatur turbin gas agar dapat dikontrol sesuai dengan keinginan operator. Data dari hasil pengontrolan disimpan dan dapat dicetak secara langsung, dimana apabila terjadi suatu masalah dalam proses produksi, maka data tersebut dapat dijadikan sebagai masukan untuk memecahkan masalah. Sensor yang digunakan untuk mengukur temperatur pada turbin gas adalah termokopel.

Penelitian ini bertujuan untuk merancang dan menguji sistem instrumentasi turbin arus pasang surut laut untuk mengukur dan memantau kinerja turbin. Data yang diukur adalah putaran turbin, tegangan dan arus yang dihasilkan generator, serta tegangan baterai. Data yang diukur ini kemudian akan disimpan di dalam flash disk yang dipasang pada perekam data. Data pengukuran tersebut juga dikirim ke operator turbin melalui layanan SMS dengan menggunakan teknologi GSM.

\section{BAHAN DAN METODE}

Bahan yang digunakan dalam perancangan perangkat keras instrumentasi turbin arus pasang surut laut adalah sebagai berikut:

1. Sistem kelistrikan turbin:

- Generator, berfungsi sebagai pengubah energi mekanik menjadi energi listrik. Generator yang digunakan adalah merk Ginlong tipe GL-PMG-1000. Spesifikasi generator tersebut dapat dilihat pada Tabel 1, sedangkan grafik/kurva daya dan tegangan generator dapat dilihat pada Gambar 1 dan Gambar 2.

Tabel 1. Spesifikasi generator Ginlong GL-PMG-1000 Table 1. Spesification of Ginlong GL-PMG-1000

\begin{tabular}{ll}
\multicolumn{1}{c}{ generator } \\
\hline \multicolumn{1}{c}{ PARAMETER } & NILAI \\
\hline Rated output power $(\mathrm{W})$ & 1000 \\
\hline Rated rotation speed $($ RPM) & 450 \\
\hline Recified DC Current at Rated Output $(\mathrm{A})$ & 6 \\
\hline Requied Torque at Rated Power & 31.5 \\
\hline Phase Resistance (Ohms) & 12 \\
\hline Output Wire Square Section (mm) & 4 \\
\hline Output Wire Length $(\mathrm{mm})$ & 600 \\
\hline Sumber: Data Spesifikasi generator Ginlong GL-PMG-1000
\end{tabular}




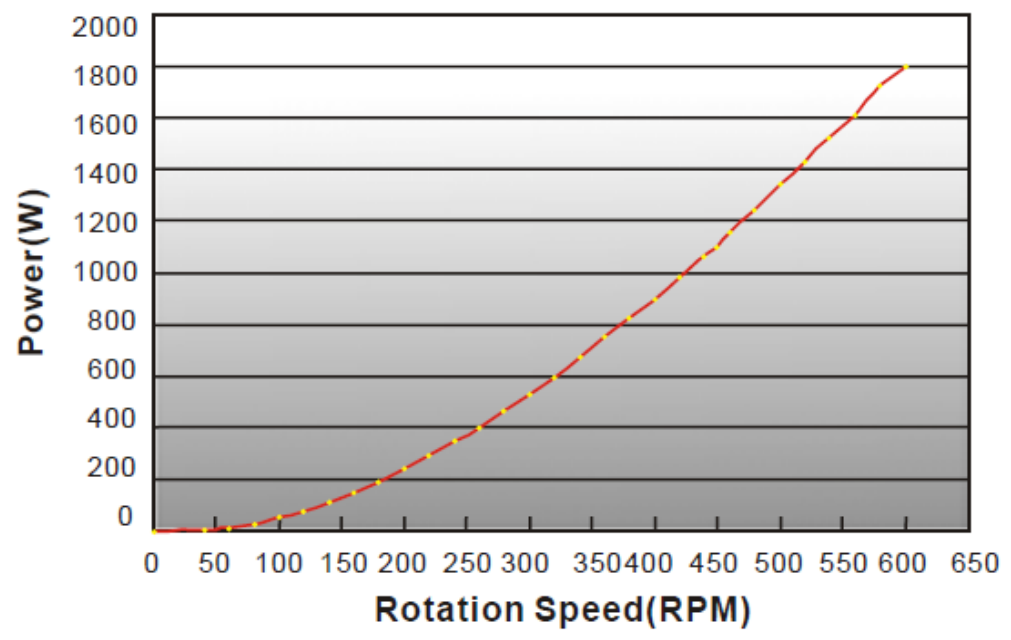

Gambar 1. Kurva daya generator

Figure 1. Power curve of generator Sumber: Data generator Ginlong GL-PMG-1000

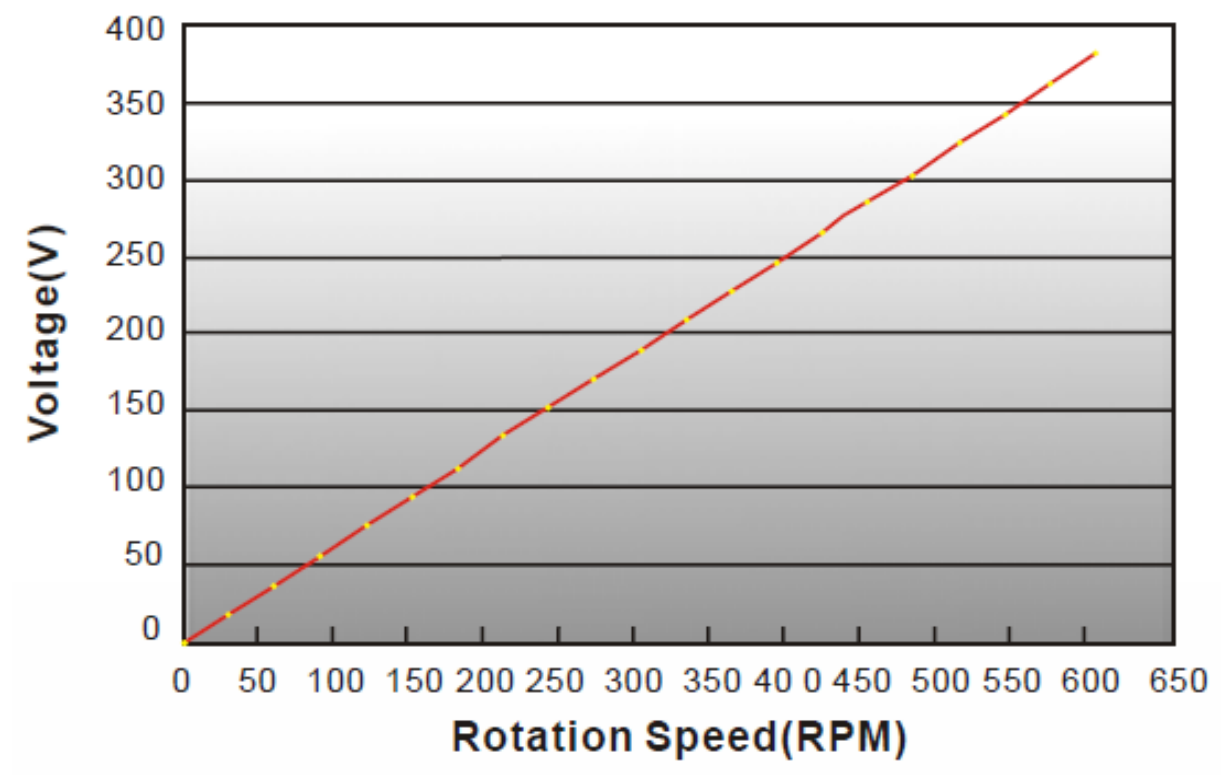

Gambar 2. Kurva tegangan generator

Figure 2. Voltage curve of generator Sumber: Data generator Ginlong GL-PMG-100

- Baterai, berfungsi untuk menyimpan daya

- Controller/rectifier, berfungsi sebagai listrik yang dihasilkan turbin. pengkondisi tegangan untuk dapat digunakan sesuai kebutuhan.

- Dump load, berfungsi sebagai alat pengaman sistem untuk membuang kelebihan daya yang diproduksi.

- Inverter, berfungsi mengubah tegangan searah (DC) menjadi tegangan bolak-balik (AC).

- Beban, berfungsi sebagai alat yang akan disuplai oleh daya yang dihasilkan turbin.

2. Modul instrumentasi

- Sistem sensor (sensor putaran, sensor arus listrik, dan sensor tegangan listrik). 
- Sistem perekaman data (data logging), melakukan penyimpanan data dengan kerapatan data tiap 8 detik. Penyimpanan data menggunakan flash disk.

- Sistem telemetri untuk pengiriman data melalui SMS menggunakan jaringan GSM. Menggunakan modul GSM dan SIM card.

Kegiatan penelitian dibagi ke dalam tiga tahapan, yaitu:

1. Perancangan sistem kelistrikan turbin

Tahap ini adalah merancang sistem kelistrikan pada turbin untuk dapat menghasilkan energi listrik.

2. Pembuatan perangkat keras modul instrumentasi
Tahap ini adalah merancang perangkat keras untuk mencatat dan menyimpan data parameter kinerja turbin. Serta merancang sistem transmisi data untuk mengirimkan data tersebut ke operator turbin.

\section{Pengujian}

Untuk mengetahui kinerja dan efisiensi turbin, dilakukan pengujian dan pengamatan skala lapangan di perairan saluran buangan air panas PLTU Muara Karang, Jakarta Utara (koordinat -6.106536 LU, 106.790767 BT) pada 15 November - 25 Desember 2012. Pertimbangan dalam pemilihan lokasi ini ialah mudahnya akses untuk uji coba dan keamanan terhadap perangkat turbin yang diujicobakan.

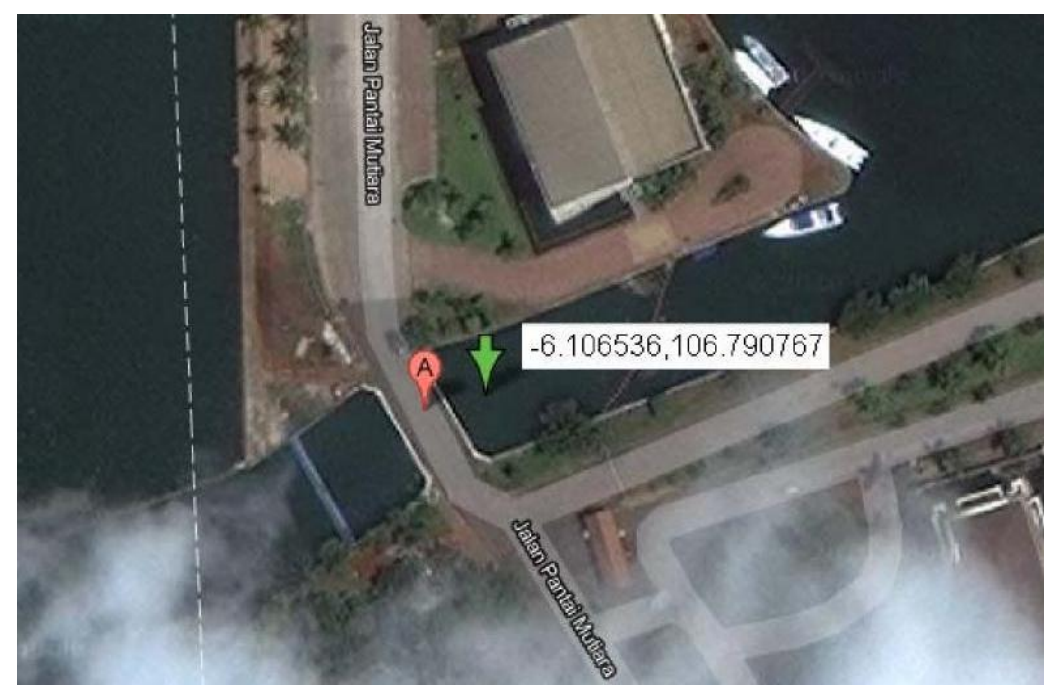

Gambar 3. Lokasi pengujian turbin arus pasang surut laut

Figure 3. Location of trial marine tidal turbine Sumber: Google Earth

\section{HASIL DAN PEMBAHASAN}

Dari perancangan sistem kelistrikan turbin, dihasilkan desain sistem kelistrikan turbin yang dapat dilihat pada Gambar 4.

Pengembangan teknologi ekstraksi energi arus laut dilakukan dengan mengubah energi kinetik arus laut menjadi energi rotasi dan energi listrik. Energi arus pasang surut merupakan salah satu bentuk energi terbarukan yang menjanjikan. Tidak seperti sumber energi terbarukan bentuk lainnya, arus pasang surut sifatnya dapat diprediksi dan terjadi secara konsisten disebabkan oleh siklus pasang surut yang dipengaruhi oleh fasa bulan (Suryansyah, 2013).

Prinsip kerja turbin dapat dijelaskan sebagai berikut. Arus laut akan menggerakkan turbin. Putaran turbin ini akan membangkitkan generator untuk menghasilkan arus dan tegangan bolak-balik (AC). Arus dan tegangan AC ini kemudian akan masuk ke pengendali (controller). Di dalam pengendali ini terdapat rangkaian penyearah (rectifier), yaitu suatu rangkaian yang berfungsi untuk mengubah arus dan tegangan $\mathrm{AC}$ menjadi arus dan tegangan DC. 


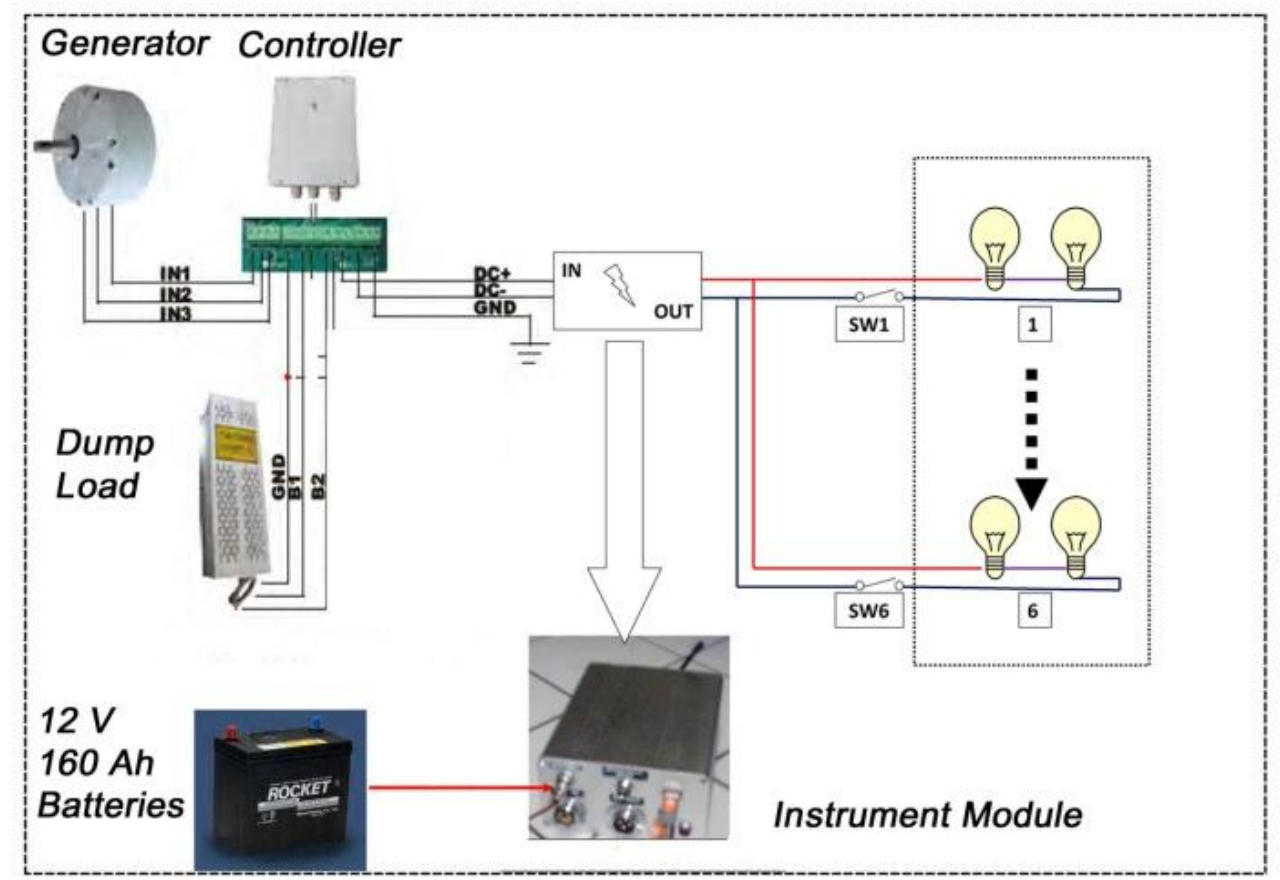

Gambar 4. Sistem kelistrikan turbin Figure 4. Turbine electrical system Sumber: Hasil pengolahan data

Hal ini dilakukan karena sistem kontrol di dalam pengendali lebih mudah dilakukan dalam posisi DC. Pengendali ini akan mengatur variasi daya listrik yang dihasilkan generator. Jika overpower, kelebihan daya tersebut akan dibuang ke dump load. Setelah melalui pengendali, daya listrik akan dialirkan ke inverter. Di inverter ini, daya listrik DC dari pengendali akan diubah menjadi AC standard $(220 \mathrm{~V}, 50 \mathrm{~Hz})$, lalu dikirim ke pelanggan.

Modul instrumentasi yang dihasilkan dapat dilihat pada Gambar 5. Modul tersebut dipasang pada turbin, digunakan untuk mengukur, mencatat, dan mengirimkan data yang dihasilkan oleh generator ke operator turbin. Modul instrumentasi yang dibuat pada penelitian ini akan mengukur dan mencatat beberapa parameter, yaitu:

- Putaran turbin (dalam rpm (rotation per minute)), maksimal $999 \mathrm{rpm}$

- Tegangan generator (volt), maksimal $700 \mathrm{~V}$

- Arus generator (ampere), maksimal $20 \mathrm{~A}$

- Tegangan baterai (volt), maksimal $24 \mathrm{~V}$

- Waktu
Modul instrumentasi ini memiliki beberapa koneksi atau sambungan, yaitu:

- Masukan (input) sensor tacho

Berfungsi untuk mengukur putaran generator.

- Masukan (input) module power

Terhubung dengan baterai DC atau adaptor AC/DC 7-24Volt.

- Masukan (input) generator

Terhubung ke controller.

- Keluaran (output) generator

Terhubung secara langsung ke beban atau inverter.

- Saklar logging

ON artinya pencatatan data sedang berlangsung. OFF artinya perangkat dalam standby mode. Modul GSM selalu dalam posisi ON.

- Lampu indikator

Lampu menyala panjang dan padam pendek, artinya modul dalam standby mode. Lampu menyala pendek dan padam panjang artinya modul sedang mencatat data.

- Konektor USB

Untuk flash disk. 


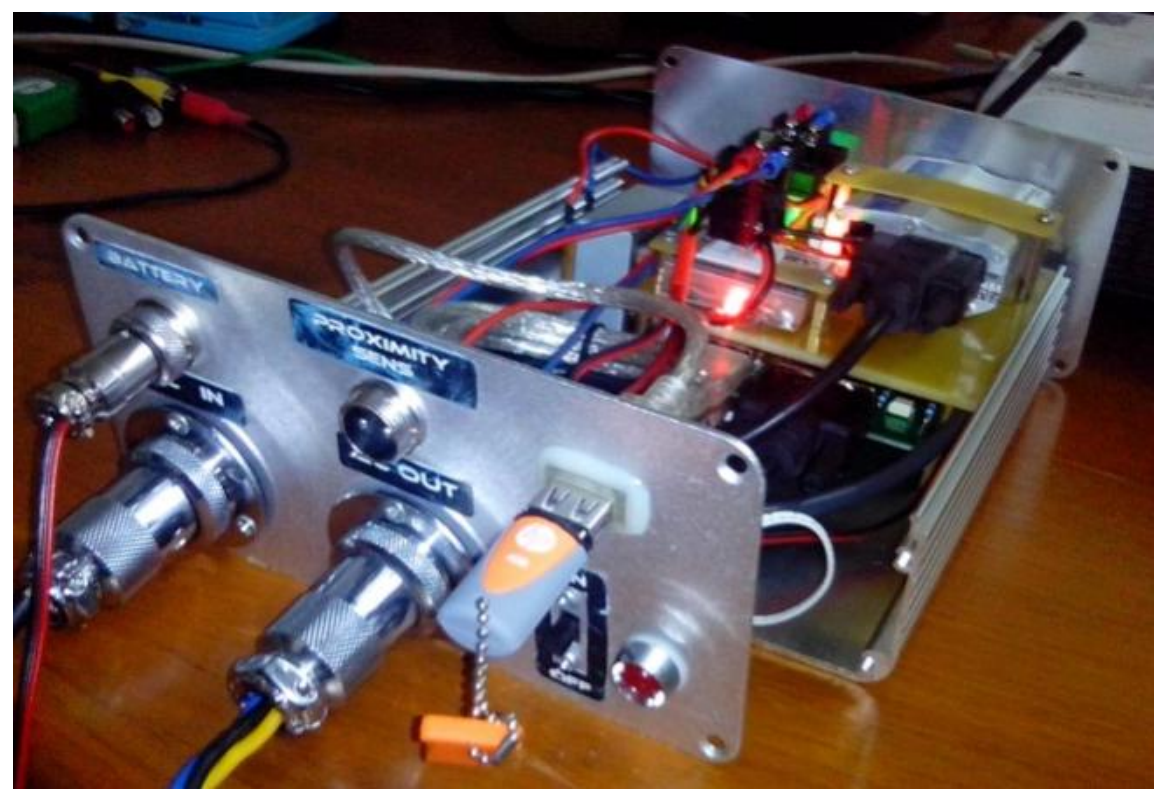

Gambar 5. Modul instrumentasi turbin arus pasang surut laut Figure 5. Instrumentation module of marine tidal turbine Sumber: Koleksi pribadi

Data yang tercatat dan tersimpan pada modul instrumentasi ini akan tersimpan dan terkirim dalam dua bentuk, yaitu:

1. Dalam bentuk $\log$ file (format .txt)

Data akan tercatat setiap 8 detik. Data setiap jam akan tersimpan pada log file yang baru. Data log file ini tersimpan pada flash disk yang dipasang pada alat (on board monitoring).

Format nama log file untuk data setiap jam adalah:

\section{LddhhmmN.txt}

Keterangan:

$$
\begin{array}{ll}
\mathrm{dd} & =\text { tanggal } \\
\mathrm{hh} & =\text { jam } \\
\mathrm{mm} & =\text { menit } \\
\mathrm{N} & =\text { nomor urutan file }(0-9)
\end{array}
$$

Format data yang tersimpan pada log file tersebut adalah:

\section{YY/MM/dd,hh:mm:ss;I=xxxxx; $=\mathbf{V x x x x ; W}$ $=\mathrm{xxxxxxx} ; \mathrm{V}=\mathrm{xxxxx} ; \mathrm{A}=\mathrm{xxxxx} ; \mathrm{R}=\mathrm{xxxx} ; \mathrm{CR}$}

\section{Keterangan:}

- $\mathrm{YY} / \mathrm{MM} / \mathrm{DD}=$ tahun/bulan/tanggal

- hh:mm:ss = jam:menit:detik
- I = arus generator (ampere)

- $\mathrm{V}=$ tegangan generator (volt)

- $\mathrm{W} \quad$ = daya (watt)

- $\mathrm{v} \quad=$ tegangan suplai ke kontroler (volt)

- A = tegangan baterai (volt)

- $\mathrm{R} \quad=$ putaran turbin $(\mathrm{rpm})$

- $\mathrm{CR}=$ nomor urut data

2. Dalam bentuk pesan singkat (SMS) via jaringan GSM.

Data dikirim ke operator turbin setiap jam. Layanan SMS yang digunakan pada penelitian ini menggunakan operator telepon seluler Indosat $^{\circledR}$. Nomor SIM card yang terpasang pada modul instrumentasi adalah 085722389101 .

Data yang terkirim melalui SMS ke nomor telepon operator turbin memiliki format sebagai berikut:

\section{MMddhh,Volt0|Amp0|RPM0|ACCU0, Volt11|Amp11|RPM11|ACCU11,EOM\#}

Keterangan:

- $\mathrm{MM}=$ bulan; $\mathrm{dd}=$ hari; $\mathrm{hh}=\mathrm{jam}$ 
- Data dikirim tiap jam, di mana data tiap jam tersebut berisi data yang diambil setiap 5 menit.

- Volt0|Amp0|RPM0|ACCU0 = data pada menit ke-0, Volt1|Amp1|RPM1|ACCU1 = data pada menit ke-5, dan seterusnya sampai menit ke-55.

- Volt adalah tegangan generator dan dinyatakan dalam 3 digit angka.

- Amp adalah arus listrik generator dan dinyatakan dalam 2 digit angka dengan skala 10 . Jika nilainya 50 artinya adalah 5 Ampere.
- RPM adalah putaran turbin dan dinyatakan dalam 3 digit angka.

- ACCU adalah tegangan baterai dan dinyatakan dalam 2 digit angka.

Uji coba turbin arus pasang surut laut dilakukan di perairan saluran buangan air panas PLTU Muara Karang, Jakarta Utara pada 15 November - 25 Desember 2012.

Hasil uji coba sistem instrumentasi pada turbin arus pasang surut laut ini dapat dilihat pada Tabel 2.

Tabel 2. Data pengujian turbin arus pasang surut laut pada 27 November 2012 Table 2. Marine tidal turbine data at $27^{\text {th }}$ November 2012

\begin{tabular}{|c|c|c|c|c|c|c|c|}
\hline Tanggal & Jam & $\begin{array}{c}\text { Arus } \\
\text { Generator } \\
\text { (A) }\end{array}$ & $\begin{array}{c}\text { Tegangan } \\
\text { Generator } \\
\text { (V) }\end{array}$ & $\begin{array}{c}\text { Daya } \\
\text { Turbin } \\
\text { (W) }\end{array}$ & $\begin{array}{c}\text { Tegangan } \\
\text { Suplai } \\
\text { Kontroler } \\
\text { (V) }\end{array}$ & $\begin{array}{c}\text { Tegangan } \\
\text { Baterai } \\
\text { (V) }\end{array}$ & $\begin{array}{l}\text { Putaran } \\
\text { Turbin } \\
\text { (RPM) }\end{array}$ \\
\hline $27 / 11 / 2012$ & 16:00:16 & 0,173 & 47,43 & 8,2 & 4,895 & 11,88 & 78,1 \\
\hline $27 / 11 / 2012$ & 16:00:24 & 0,167 & 58,86 & 9,8 & 4,895 & 11,88 & 126,4 \\
\hline $27 / 11 / 2012$ & 16:00:32 & 0,171 & 58,46 & 10 & 4,895 & 11,88 & 89,4 \\
\hline $27 / 11 / 2012$ & 16:00:40 & 0,139 & 27,81 & 3,9 & 4,895 & 11,88 & 69 \\
\hline $27 / 11 / 2012$ & 16:00:48 & 0,165 & 48,91 & 8,1 & 4,895 & 11,88 & 92,4 \\
\hline $27 / 11 / 2012$ & 16:00:56 & 0,169 & 30,34 & 5,1 & 4,895 & 11,88 & 71,7 \\
\hline $27 / 11 / 2012$ & 16:01:04 & 0,107 & 10,96 & 1,2 & 4,895 & 11,88 & 37,1 \\
\hline $27 / 11 / 2012$ & 16:01:12 & 0,165 & 57,73 & 9,5 & 4,895 & 11,88 & 121,1 \\
\hline $27 / 11 / 2012$ & 16:01:21 & 0,169 & 41,61 & 7 & 4,895 & 11,88 & 85,3 \\
\hline $27 / 11 / 2012$ & 16:01:29 & 0,153 & 43,66 & 6,7 & 4,895 & 11,88 & 108,1 \\
\hline $27 / 11 / 2012$ & 16:01:37 & 0,155 & 17,86 & 2,8 & 4,895 & 11,88 & 45,1 \\
\hline $27 / 11 / 2012$ & 16:01:45 & 0,161 & 65,79 & 10,6 & 4,895 & 11,89 & 114,4 \\
\hline $27 / 11 / 2012$ & 16:01:53 & 0,159 & 33,68 & 5,4 & 4,895 & 11,89 & 68,2 \\
\hline $27 / 11 / 2012$ & 16:02:01 & 0,179 & 32,08 & 5,7 & 4,895 & 11,89 & 61,8 \\
\hline $27 / 11 / 2012$ & 16:02:09 & 0,157 & 26,79 & 4,2 & 4,895 & 11,88 & 54,1 \\
\hline $27 / 11 / 2012$ & 16:02:17 & 0,181 & 53,06 & 9,6 & 4,895 & 11,89 & 93,9 \\
\hline $27 / 11 / 2012$ & 16:02:25 & 0,101 & 0 & 0 & 4,895 & 11,88 & 42,9 \\
\hline $27 / 11 / 2012$ & $16: 02: 33$ & 0,135 & 7,76 & 1 & 4,895 & 11,88 & 29,4 \\
\hline $27 / 11 / 2012$ & $16: 02: 41$ & 0,193 & 55,16 & 10,6 & 4,895 & 11,88 & 93,8 \\
\hline $27 / 11 / 2012$ & 16:02:49 & 0,143 & 9,63 & 1,4 & 4,895 & 11,88 & 33,3 \\
\hline
\end{tabular}

Data pada Tabel 2 berasal dari data yang disimpan pada data logger. Data tersebut merupakan data pengujian turbin arus pasang surut laut pada 27 November 2012 pukul 16:00:16 hingga pukul 16:02:49.
Dari Tabel 2, terlihat bahwa data dicatat dan disimpan setiap 8 detik. Dari data hasil pengujian pada 27 November 2012 pukul 16.00, dapat dibuat grafik seperti pada Gambar 6 sampai Gambar 7. 


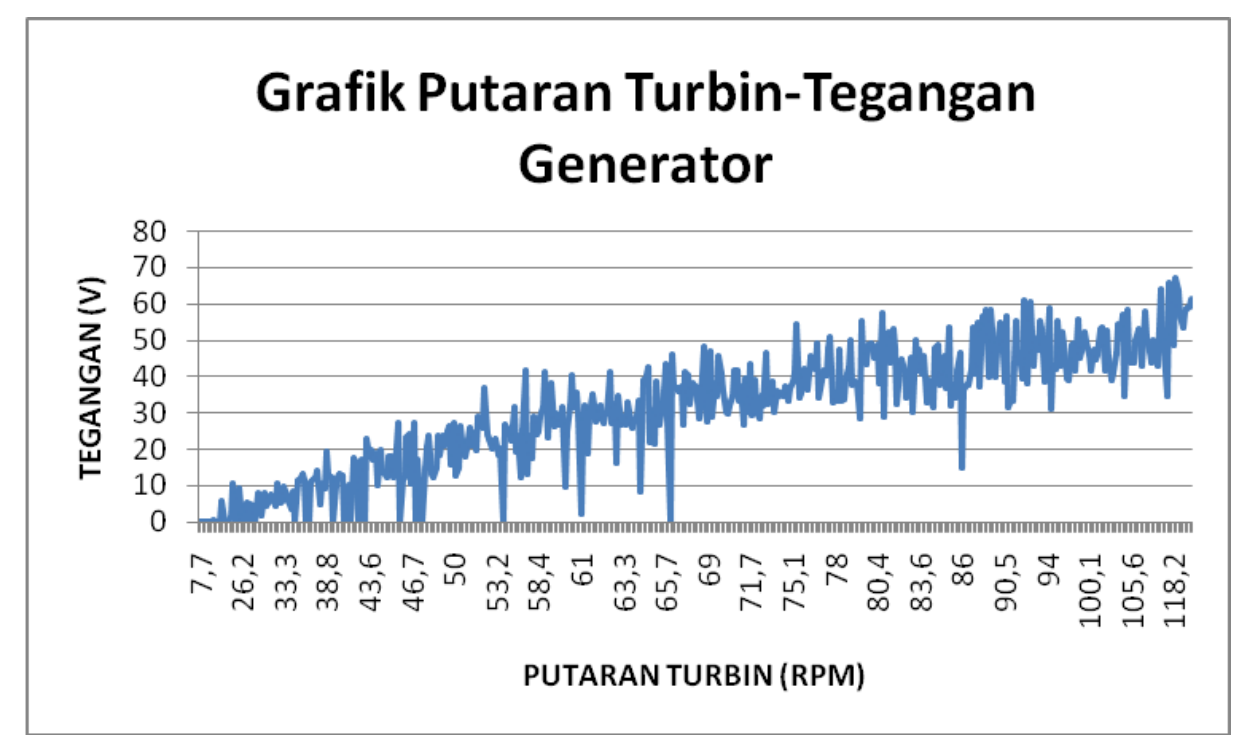

Gambar 6. Grafik perbandingan putaran turbin dengan tegangan generator pada 27 November 2012 pukul 16.00

Figure 6. Chart of comparing of turbine rotation and generator voltage at $27^{\text {th }}$ November 201216.00

Sumber : Hasil pengolahan data

Gambar 6 adalah grafik perbandingan antara putaran turbin dengan tegangan generator. Terlihat bahwa secara umum, tegangan generator akan naik seiring dengan kenaikan putaran turbin. Tetapi kenaikan tersebut fluktuatif.
Grafik ini dapat dibandingkan dengan kurva tegangan generator pada Gambar 2. Pada Gambar 2 , tegangan generator akan naik secara linier dengan putaran turbin.

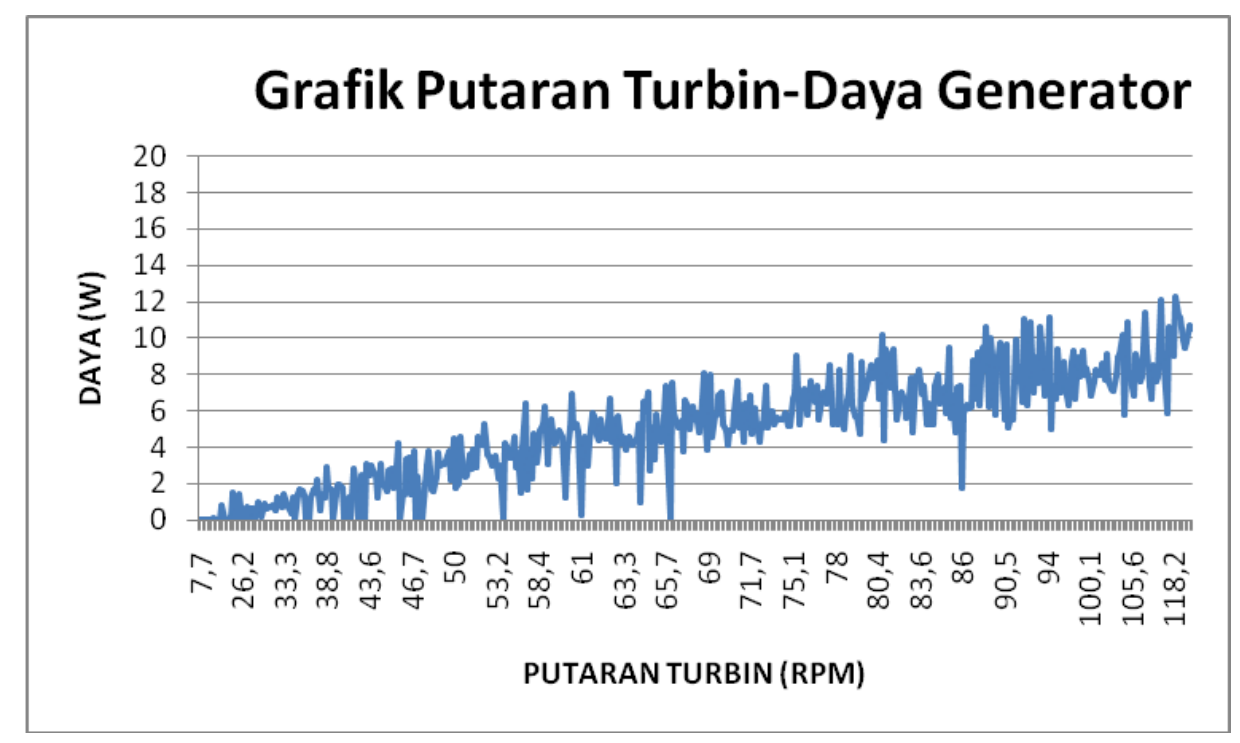

Gambar 7. Grafik perbandingan putaran turbin dengan daya generator pada 27 November 2012 pukul 16.00

Figure 7. Chart of comparing of turbine rotation and generator power at $27^{\text {th }}$ November 201216.00 Sumber : Hasil pengolahan data

Gambar 7 adalah grafik perbandingan antara putaran turbin dengan daya generator. Terlihat bahwa secara umum, daya generator akan naik seiring dengan kenaikan putaran turbin. Tetapi kenaikan tersebut fluktuatif. Grafik ini dapat dibandingkan dengan kurva daya generator pada Gambar 1. Pada Gambar 1, daya generator akan naik secara eksponensial dengan putaran turbin.

Instrumentasi Pemantauan Jarak Jauh untuk Mengukur Kinerja Turbin Arus Pasang Surut Laut - Hadhi Nugroho dan 
Perbedaan ini disebabkan oleh beberapa faktor, seperti naik turunnya kecepatan arus laut pada uji coba di lapangan.

Contoh data yang dikirim melalui layanan SMS ke operator turbin adalah sebagai berikut:

112716,0470107811,0470107711,0520109511,036

$0107511,01201044,04901080,0350106711,033010$

7711,0410107611,0170104711,0080103411,EOM

\#

Paket data tersebut merupakan paket data turbin selama 1 jam pada 27 November 2012 pukul 16.00-17.00. Paket data tersebut berisi data turbin setiap 5 menit, dari menit ke-0 sampai menit ke-55. Data yang dikirim melalui SMS ini diambil dari data log file yang disimpan pada flash disk. Setiap data dipisahkan dengan koma. Sebagai contoh data pada menit ke-5 adalah 0470107711. Arti data tersebut adalah nilai tegangan generator sebesar 47 $\mathrm{V}$, arus generator $0,1 \mathrm{~A}$, putaran turbin $77 \mathrm{rpm}$, dan tegangan baterai $11 \mathrm{~V}$. Perbedaan dengan data pada log file adalah bahwa data SMS ini nilai parameter turbin tidak menggunakan desimal (pembulatan).

Data uji ini menunjukkan bahwa perangkat keras instrumentasi berhasil mencatat dan menyimpan parameter kinerja turbin arus pasang surut lautdengan baik. Data tersebut juga berhasil terkirim ke operator turbin menggunakan layanan SMS. Hal ini menunjukkan bahwa pembuatan perangkat keras instrumentasi pengukuran kinerja turbin arus pasang surut laut telah berhasil dan berfungsi dengan baik.

\section{KESIMPULAN DAN SARAN}

Telah berhasil dibuat perangkat keras instrumentasi turbin arus pasang surut laut. Perangkat tersebut dapat berfungsi dengan baik dalam mencatat, menyimpan, dan mengirimkan data parameter kinerja turbin. Data tersebut adalah tegangan generator, arus generator, putaran turbin, serta tegangan baterai.

Data parameter kinerja turbin tersimpan dalam bentuk $\log$ file (.txt). Data tersebut tercatat dan tersimpan setiap 8 detik. Data setiap jam akan tersimpan pada log file yang baru. Data log file ini tersimpan pada flash disk yang dipasang pada turbin (on board monitoring).
Data parameter kinerja turbin juga berhasil terkirim ke operator turbin melalui SMS, dengan waktu pengiriman data setiap satu jam. Data setiap jam tersebut berisi data turbin setiap 5 menit.

Dari data hasil uji coba, dapat dibuat grafik hubungan antara putaran turbin dengan tegangan generator dan putaran turbin dengan daya generator. Pada grafik putaran turbin dengan tegangan generator dan putaran turbin dengan daya generator, diperoleh hasil bahwa secara umum tegangan generator dan daya generator akan naik seiring dengan kenaikan putaran turbin, dengan kenaikan bersifat fluktuatif.

Dengan sistem instrumentasi, kinerja turbin arus pasang surut laut yang dipasang di suatu tempat dapat dipantau dari jarak jauh secara terus-menerus dan real time.

\section{DAFTAR PUSTAKA}

Anonim. (2011). Data Logger (bagian 1). Diakses 6 Mei 2011 dari: http://www.sonoku.com.

Ariyus, D. dan Andri, R.K.R.. (2008). Komunikasi Data. Yogyakarta: Andi.

Darajat, A.U., Komarudin, M. dan Sulistiyanti, S.R. (2012). Sistem telemetri unmanned aerial vehicle (UAV) berbasis inertial measurement unit (IMU). Electrician Jurnal Rekayasa dan Teknologi Elektro 6 (3), 169-177.

Oemry, A. dan Djunaedi, I. (2010). Sistem monitoring pembangkit listrik hibrit sel surya, turbin angin, fuel cell berbasis hidrogen. Jurnal Sains MIPA, $16(1), 57-61$.

Pasaribu, P. (2006). Evolusi Teknologi Telekomunikasi Bergerak: $1 G$ to 4G. Diakses 9 Oktober 2012 dari: http://www.ilmukomputer.org/wp-content/ uploads/2006/09/ parlin-mobile.pdf.

Republik Indonesia. (2010). Peraturan Menteri Komunikasi dan Informatika No. 01/PER/M.KOMINFO/01/2010 tentang Penyelenggaraan Jaringan Telekomunikasi. Jakarta.

Riyadi, M. Z. (2011). Pengontrolan Temperatur pada Turbin Gas MS-5002 Menggunakan Speedtronic (Aplikasi PT. Arun NGL). Karya Akhir D4. Universitas Sumatera Utara. Medan.

Rossy, C., Utomo, W. H., dan Wellem, T. (2006). Perancangan dan implementasi sistem informasi layanan short messaging service (SMS). Jurnal Informatika 2(2), 155 - 166.

Setiawan, I. (2009). Buku Ajar Sensor dan Transduser. Semarang: Program Studi Sistem Komputer, Fakultas Teknik, Universitas Diponegoro. 
Sukiswo. (2005). Perancangan telemetri suhu dengan modulasi digital FSK-FM. Transmisi 10(2), 1- 8.

Suryansyah, Y. (2013). Potensi energi arus laut untuk pembangkit tenaga listrik di pulau-pulau kecil (Studi: Pulau Mantang di Bintan, Pulau Abang di Batam, dan Pulau Sugi di Karimun, Propinsi Kepulauan Riau). Jurnal Kelautan Nasional 8(1), 27-34.

Syariman, P. (2012). Perkembangan dan Aplikasi Telemetri dalam Bidang Sumber Daya Air di Indonesia. Jakarta: Pusat Penelitian dan Pengembangan Sumber Daya Air, Badan Penelitian dan Pengembangan Kementerian Pekerjaan Umum. 44 hlm.

Warsito, A. (2009). Pengantar Instrumentasi. Diakses 9 Oktober 2012 dari: http:// alifis.files.wordpress.com/2009/09/seri_elinspengantar-instrumentasi.pdf.

Wijayanto, W. (2012). Rancang Bangun Sistem Monitoring Kecepatan Turbin Generator Pada Miniplant Mikrohidro Skala Laboratorium di Workshop Instrumentasi. Tugas Akhir D3. Institut Teknologi Sepuluh Nopember, Surabaya. 